\title{
Tattua
}

JOURNAL OF PHILOSOPHY

\section{VISION OF ORGANIC WHOLE: PROCESS THOUGHT AND SIDDHA CULT}

\section{Vallabadoss John Peter, Ph.D}

The unifying vision of Process thought developed by Whitehead helps re-visioning and re-interpreting Indian heritage. Enthusiasm in revival of rich ancient and classical traditions is trendy in contemporary Indian philosophical scenario. Siddhas of South India, widely known as naturopathic physicians and socio-religious rebels, have greatly contributed to philosophical thinking. Process, as a method of inquiry into a specific form of conceptual frame work, means, in the words of Kurian Kachappilly, "a dynamic network of connections and interconnections leading to a creative synthesis. "It has the significance of interconnectedness and interdependence in any organic whole. The organic whole is to be found in the body and universe. Siddha cult has a similar approach to reality as in Process Thought. As Process Thought is all about 'a dynamic network of connections and interconnections' and a holistic vision of reality, an enquiry into Tamil Siddha Philosophical trends would be beneficial in making Process interlinked with Eastern perspectives.

\section{Siddha Concept of God}

Concept of siiva or god in Indian tradition is both theistic and absolutist. Theistic conception of siva is very much developed in the bhakti period by the siaiva saints. Saivism propagated personal and devotional relationship to siiva. Siddhas

01. Kurian Kachoppilly, Process: Implications and Applications, Bangalore: Dharmaram, 2006, 1. 
have spoken about impersonal conception of 'Sivam' as supreme abstraction meaning 'it' or 'adu' or thainess or 'suchness' or para 'param. In Siddha cult, the absolutist approach to siiva is deeply rooted. Kailasapathy observes, "[...] the Siddhas were not devotees in the sense of idol worshippers... they believed in a supreme abstraction. "2 For them 'Sivam' is an abstract noun meaning 'goodness' auspiciousness. The common term 'sivan' refers to personal god. In their profound understanding of God, the Siddhas did not consider worshiping individual deities in any particular temple. Singing the praises of local deities is the difference between the Siaiva and Vaishnava bhakti saints and Siddhas. ${ }^{3}$ Siddhas do not advocate personal characters of God. Their rejection of personal god and individual characterization of the Supreme Being is meant nof for rejecting any relation to that absolute being. Their rejection is out of their conviction that any rigid theism leads to unnecessary controversy and hostility among different followers of different religions. ${ }^{4}$ For the Siddhas, worship is nof usual ritualistic practice but true worship of heart. ${ }^{5}$ In the explanation of nature of Souls, the interrelationship between Divine and Human is specified. The world origination is done according to the karma of the soul, for the sake of liberation of the souls. God, in his kindness is gracious enough to attach respective bodies to the souls.

\section{God and World Process}

For the Siddhas God essentially interacts with the world. God is said to be effecting the cosmic processes of creation, preservation and destruction, which both soul and world undergo. Through his siròsòti siakti, he creates the material world; through his sthiti siakti, he preserves it; through sam "ha- ra siakti, he destroys the world; through his tirobha'va siakti, he conceals the true noture of world and allows the soul to be attracted and yield to temptations of the world; and finally through his arul siakti, he reveals the true nature of world and makes the soul to withdraw from the world and turn towards him. The cosmic processes of creation, preservation and destruction are being repeated in continued succession in a cyclic form. God is conceived as an efficient cause and as a supreme intelligence and will to accomplish cosmic process.

02. K. Kailasapathy, "The Wrilings of the Tomil Siddhos," in The Sants: Studies in Devotional Tradition of India, 313. As cited in T.N. Ganapothy, The Philosophy of Tamil Siddhas, 71.

03. T.N. Ganapathy, The Philosophy of Tamil Siddhas, New Dehli: ICPR, 2004, 19.

04. B. Natarajan, trans., Tirumandiram, no. 1533, 1568 (Chennai: Ramakrishna Moth, 2002), $239 \& 244$.

05. Tinumandiram - 197. 
Process holds that God interacts with the process of the universe. The ultimate reality is creativity continually producing new unities of experience out of the manifold of the previous moment. Creativity is not something additional to actuality. To what actually exists at a given instant there is a creative power within. Every actuality is a momentary event, with creativity. ${ }^{6}$ Eoch occasion and a stream of occasions, has power within. God gives the best possibility to each occasion as it creates itself. ${ }^{7}$ Each occasion is a moment of experience and harmony is embodied in it. The discord in this harmony is evil which "... is the feeling of evil in the most general sense, namely physical pain or mental evil, such as sorrow, horror, dislike. ${ }^{\prime 8}$ The evolution of the universe as a whole is due to divine impetus to create harmony in present occasion and for new possibilities in the future.

\section{Souls and World}

In a curious quest for the meaning of existence, human beings conceptualize what could reality be, in terms of their relationship with the physical and non-physical phenomena around them. Tamil Siddha cult enumerates its profound thought pattern on the world-matter as an essential substratum of the natural world in and around the human beings and as the undeniable constituent part of their beings. The world-matter, which is termed as ' ma $^{-} \mathrm{yo}^{-}$', thus, basically forms the foundations of the natural world and the human bodies. Siddha thought constructs its concept of the world-matter, as that which is not something unrelated and remote from the Divine and the Human Beings, rather, as that which is very much interconnected and inter related with them.

In passing from impure state to pure state, the soul undergoes three stages called 'ovastha's,' namely, kevola avastha', sakala avastha and suddha avastha. In the first stage the soul is lonely with a-nòava and karma, covering and overshadowing it. In the sakala stage, taking a body, the soul enters the world and interacts with the objects of the world made out of matter, or ma ${ }^{-} y$. Through the kriya" siakti or power to act, the soul engages in human activities, which incur upon its karma, the fruits of actions, namely reward and punishments. To enjoy the consequences of its good and bad deeds, the soul is granted various lives and different embodiments. Passing from one life to another in different bodies, the soul lives in sam ${ }^{-} \mathrm{sa}^{-} \mathrm{ra}$. At the time of realization, it turns away from pursuing the world

06. John Hick, Philosophy of Religion, New Delhi: Prentice Hall, 1987, 50.

07. A.N. Whitehead, Religion in the Making, New York: Cambridge University Press, 1930, 51. As cited in Hick, 51.

08. A.N. Whitehead, Adventures of ldeas, New York: Cambridge University Press, 1933, 330. As cited in Hick, 51. 
and turns towards the Divine. Eventually, all its acts are now not its own, but become God's acts. Here the soul does not incur any karma as such, though if lives in body and interacts with the material world. As V. Paranioti observes the biographies rendered in Sekkilar's Periyapuranam, "Biographies [...] show how these jivanmuklas are not withdrawn from the world. Those of them who had wealth regarded it as a trust in their hands to be used for the needy. ${ }^{\prime \prime}$ In this last stage, the soul is a liberated soul, as jivanmukla while living in body. The interaction and interconnection between the soul and the matter are thus explicated well.

'World is for the humans' is the notion that would characterize the Siddha thought. Scientific temper today distanced humans from the nature. All the sciences, including medicine, tend to go 'away' from nature or go 'against' nature. Human outlook on Nature guides human relationship with Nature. Corrective to notions of dichotomy between human and nature would enable the contemporary human sociely to address the issues of alienation from the nature. Alternative vision of humannature relationship in terms of holistic outlook is the need of our times. Siddha Philosophy offers such vision. As Tirumular says that a person who understood thoroughly that the microcosm and the macrocosm are one and the same and a person who experienced this oneness in him is a true Siddha. ${ }^{10}$

\section{Universe and Human Body: Made of Five Elements}

The primordial five elements (Bhu ${ }^{-}$tos) are present in every substance, but in different proportions. The human being is made up of these five elements, in different combinations. The human anatomy and physiology, causative factor of diseases, the materials for the treatment and cure of the diseases, the foods for the sustenance of the body, all fall within the five elemental categories. "The maintenance of the equilibrium is health, disturbance is disease. In Siddha method of treatment, the drugs are made up of the five elements. By substituting a drug of the same constituents (gunòa) the equilibrium is restored. As the universe is composed of the five bhu ${ }^{-}$tos so are human body and the medicines. Siddhas demonstrated that the macrocosm is reflected within the microcosm and emphosized that the universe, in all its totality, is contained within the body of the individual. Cattamunicittar explains that the human body is the part of the universe and that the body and

09. Ibid. p.33.

10. Tirumandiram, 124.

11. Dr. V. Narayanaswami. Introduction To The Siddha System of Medicine, Madras: Research Instituje of Siddha Medicine, 1975, 6. 
universe are one and the same and are inseparable. ${ }^{12}$ The forces operative in the universe are also in existence in the human body. "The forces which manifest themselves through actions of the various parts out of the body have a close relation with the outside forces in the universe. ${ }^{\prime \prime} 3$

Human beings consume water and food, breathe the air and then maintain the heat in the body. Human life is because of the life force given by ether. Anatomical division of human body is rendered as legs as prithvi, abdomen as appu, chest as theyu, neck as vayu, head as akayam. All five elements of nature shape the characteristic feature of human mental and spiritual faculties. ${ }^{14}$ A suitable proportion of these five elements in combination with each other sustain a healthy person.

\section{The Sacred Human Body}

Siddhas attribute great importance to Human body. Human body is referred to as 'kuppai, multai, vi" du, uppukkudu, athippalam, pa'nai, aindhagam, kurambai, pandal, ko "yil, tirumeni, venkotam, srirangam, aduthurai, thanjavur. ${ }^{15}$ Besides expressing the human body as realistically as possible, they referred to it as a holy and sacred place. Sivavakkiyar says that it is a waste to go to sacred rivers, temples and places while they are within us. ${ }^{16}$ Tirumular relates that the human body itself is the temple of the Goddess Shakti. ${ }^{17}$ Siddhas valued human body as a medium through which one attains final human goal of liberation. ${ }^{18}$ They treated the body as the best medium of realizing the truth. Siddhas expressed their conviction very strongly that God can be seen in the body itself. ${ }^{19}$ The body contains in itself an immortal essence. It is an instrument of liberation, when transformed into a divine body. Eternity is within the body. This dehajnPa "nam of Siddha philosophy reflects tantric doctrine of 'siari" ramadyam khalu dharmasa ${ }^{-}$danam. ${ }^{20}$ However, some

12. "Andaththil Ullothe Pindam; Pindaththil Ullathe Andam; Andamum Pindamum Ontre; Arindhuthan Parkkum Pluthe"

13. S. Prema, "Role of Siddha Medicine in Indigenous Systems of Medicine," in Socio-Cultural Aspects, Modros, IITS, 1994, 384.

14. Manos, Cittar Padalgal - Songs of Siddhas (Tamil), Chennai: Paonkodi Pattipagàm, 1995, 42-47.

15. Refer; T.N.Ganapathy, The Philosophy of the Tamil Siddhas, 181.

16. Sivakkiyar, 17, 23.

17. Tirumandiram, 730 .

18. Somu, Me, Pa. Cittar Illakiyam - Siddha Literature (Tamil), Vol. 1, Annamalai Nagar: Annamalai University, 1992, 97.

19. P. Jaya, "Siddha Movement as Social Revolt," in Social Heritage of the Tamils, Chennai: IITS, $2003,85$.

20. Ibid. 
of the Siddha poems certainly contain pessimistic and cynical expressions towards woman as temptress and the human body as filthy. They are meant to trigger human consciousness towards higher values more than shallow values and to teach the people to go beyond the level of physical and achieve an immortal body. Siddhas' attitude towards human body is entirely positive. ${ }^{21}$

The Siddha medicine deals with kaya kalpa sadhana ${ }^{22}$ to cure diseases and to prolong lifespan. It serves as constructive medicines and is for the transformation of the body into immortal essence. ${ }^{23}$ Through koya sadhana one makes an attempt to attain a perfect body which Tirumular called as siddha deha. ${ }^{24}$ As S. A. Sarma puts it, "Kaya-siddhi or the perfection of human body, rightly then, comes to be the primary aim and concern of the disciplines of the Tamil Siddhas, especially of their alchemical teachings and practices. ${ }^{.25}$ Siddhas' alchemy is based on a theory that a person who knows the secrets of five elements could change a base metal into gold. Even though alchemy is not the primary goal, alchemical ideas dominate Siddha medicine. Siddhas tried to evolve drugs that could arrest the decay of the body. Siddhas are different kind of alchemist in their conception and practice. "Just as the alchemist works on base metals and furns them into gold, the siddha transmutes his psycho-physical life into a free autonomous spirit. ${ }^{26} \mathrm{Gold}$, in siddha philosophy would symbolize immortality. T.N.Ganapathy calls siddhas as 'spiritual alchemists. ${ }^{27}$ As Tirumular states, "There is no perishing for the body, ${ }^{28}$ by transforming the gross body into illuminated body, immortality is achieved. ${ }^{99}$ "The ancient Indians thus intensely felt themselves as inseparable part and indispensable members of the huge family of the cosmos. ${ }^{130}$ The Siddha system is yogic, meaning union between matter and spirit, body and soul, human and material Nature. Siddha philosophy is therefore a right orientation towards a harmony, holistic understanding of human being and right relationship between human beings and natural environment.

21. Ibid. 116.

22. Agappeyccittar, 26.

23. T.N.Ganapathy, Tamil Siddhas, 9.

24. Tirumandiram, 93.

25. S. A. Sarma, Tamil Siddhas, New Delhi: Munshiram Manoharlal, 2007, 109.

26. T.N.Ganapathy, Tomil Siddhas, 9.

27. Ibid.

28. Tirumandiram, 581 .

29. K. Narayanan, Cittar Thathuvam - Philosophy of the Siddhas (Tamil), Puducherry: Mari Pathipagam, 1988, 91.

30. Kurian Kachoppilly, Process, 41. 


\section{Unity of All Creation}

The unity of all creation is the vision of the Siddhas. The Siddhas present a world view wherein all living and non-living beings are bound together and form this organic whole. Siddha tradition has frequent and significant references to ecological thoughts that are of confemporary relevance in terms of upholding the vision of wholeness. Ecological thoughts in Siddha tradition have envisioned fundamental elements that are united with great rhythm. Highlighting the interconnectedness and interdependence contributes substantially to organic whole. In ecological thinking god is to be understood as intimately connected with the world and humans. Eco philosophy envisages a relational image of god-human-world. "Let the whole world attain the bliss that I have received. ${ }^{\text {"3l }}$ And "Mankind is one family and god is one." ${ }^{\prime \prime 2}$ These words of Siddhas promote kinship among the humans and with one another in order to respect for life. Siddhas express the process principle of 'unity of life' that exists in all living things. Sensitivity to this unity of life is the rationale to adopt a 'holistic' attitude to life and nature, and a profound appreciation for nature and for the sanctity of nalure. Again in their Broad vision for humanity, the Siddhas have spelt out the praxis of achieving this while denouncing the oppressive structures. Powerful protest voice of Siddhas against dehumanizing socio-religious situation of India is loud enough in the context of alienation, domination and exploitation. Siddhas' vision of humanity is holistic and organically related.

\section{Interconnectedness of Reality}

Process thought that everything is made up of events and that every event is interrelated. God, soul and matter are the three eternal substances that constitute reality. Tirumular one of the siddhas, in his Tirumandiram, sums up the understanding of threefold reality, saying, "pati pasu pasam enappagar...." ${ }^{\prime 3}$ Pati or God, Pasu or Soul, and Pasam or Bonds, all three are said to be eternal, beginningless. Pasam would not approach Pati by its own effort, as it is inert and unintelligent. Pasu too is not able to reach up to God due to bondage. Yet, with his grace God nears the soul to relieve if from the power of bondage and make it surrender totally to God. The pluralist vision of reality upholds not 'non-connected, 'separated' or not even juxtaposed entities. All the three are necessarily interconnected, mutually interrelated and essentially interactive. Even explanation of the nature of each one is intricate and involved, due to their intertwined and interdependent character of

31. "yan petira inbam perugo iwaiyam." Tirumandiram, 85.

32. "Ontre kulamum oruvane tevanum." Tirumandiram, 2104.

33. Tirumandiram, - 115 . 
these concepts and the knowledge about them. Whether in state of bondage or liberation, they are interrelated very closely, or even inseparably. Interrelationship is further explained in the following way, as J.J. Rai puts it, "...the Supreme One is the concerned Lord; spirits-in-bondage... is His central concern in the unfolding of history; and the beauteous world is the setting His concern provides, to lead the estranged man fo liberation from bondage, and to communion with Him in Bliss (mukthi). ${ }^{135}$

\section{Vision of Organic Whole}

A philosophy of organism includes not just topographic and climatic factors in the surroundings but organisms. ${ }^{36}$ Life is "a dynamic network of connections and interconnections leading to a creative synthesis. ${ }^{137}$ Siddha conception of human life with dynamism of the cosmos is a philosophy of organism. Siddha vision of organic whole is traced out in the interconnections and interdependence among human organism, natural beings and the cosmos, envisioned both in physical and metaphysical levels. "The Tamil Siddha school of Indian philosophy conceives of nature not in terms of sentiency and insentiency, nor as consciousness and unconsciousness, nor again as matter and mind - in short, the school does not conceive of Nature in terms of pairs of opposites. ${ }^{\prime \prime 8}$ World is God's manifestation, god is in the world. Humans are gods. God, human, other living beings and nature form a one organic whole.

Siddhas committed themselves to build a strong bond of God-human-nature relationship. Siddhas have left us tremendous treasure of a unique and matchless philosophy of holistic vision of unity. Siddhas' conception of human life with dynamism of the cosmos is indeed a philosophy of organism. Siddhas' vision of organic whole is traced out in the interconnections and interdependence among human organism, other living beings and the cosmos, envisaged both in physical and metaphysical levels. Process is ultimately combined with the primacy of relationship. God being related to the world and humans is basically in the Siddha conception of reality. God would no longer be thought without human beings and without the world. Siddhas' vision of humanity is holistic and organically related. Siddha tradition

34. Joseph Jaswant Raj, Grace in the Soivo Siddhontham and in St. Paul, Madras: Salesian Society, 1989, 57.

35. Ibid. 59.

36. Kurion Kachappilly, Process, 38.

37. Alfred N. Whitehead, Process and Reality: An Essay in Cosmology, New York: The Free Press, 1979, 21.

38. S. A. Sarma, Tamil Siddhas, New Delhi: Munshiram Manoharfal, 2007,103. 
has frequent and significant references to ecological thoughts that are of contemporary relevance in terms of upholding interrelations and interdependence in Human-Nature relationship. Siddha concept of 'onòdame pinòdam' - whole cosmos is in the body - emphasizes harmonious human-nature relationship. The Siddhas present $a$ world view wherein all living and non-living beings are bound together and form an organic whole. If the end goal of process is 'towards a creative synthesis,' Siddha vision of humanity intrinsically and organically related with the Divine and Noture proceeds towards such a holistic synthesis. What the humans are and what they are yet to become is in process. It is indeed a vision of becoming. The vision of Organic Whole in both Process and Siddha thought is Being and becoming of Godly Human in the world. 